\title{
SOIL PROPERTIES, LEAF NUTRIENTS AND FRUIT QUALITY RESPONSE TO SUBSTITUTING CHEMICAL FERTILIZER WITH ORGANIC MANURE IN A MANGO ORCHARD
}

\author{
FenG, H. D. ${ }^{1 \dagger}-$ CHEN, H. Y. $.^{2 \dagger}-$ DANG, ZH. G. ${ }^{1}-$ NI, B. ${ }^{3}-$ He, C. C. ${ }^{1}-$ WeI, ZH. Y. ${ }^{1}-$ CHEN, Y. Y..$^{*}$ \\ ${ }^{I}$ Tropical Crops Genetic Resources Institute, CATAS, Haikou, Hainan 570211, China \\ ${ }^{2}$ Rubber Research Institute, CATAS, Haikou 571101, China \\ ${ }^{3}$ Modern Agricultural Inspection Testing Control Center of Hainan Province, Haikou 571101, \\ China \\ *Corresponding author \\ e-mail: chenyy1962@126.com; phone: +86-138-0758-2106 \\ ${ }^{\dagger}$ These authors contributed equally to this study. \\ (Received 22 $2^{\text {nd }}$ Dec 2019; accepted 23 ${ }^{\text {rd }}$ Mar 2020)
}

\begin{abstract}
It is highly significant to reduce the amount of chemical fertilizer application in mango orchards and substituting it with organic manure. The field location method was applied to examine the effects of substituting chemical fertilizer with organic manure on soil physical and chemical properties, leaf nutrients, fruit yield and quality in a mango orchard, it can provide a foundation for reducing chemical fertilizer application in mango orchards. Results indicated that, compared to conventional fertilization, treatments substituting chemical fertilizer with organic manure at different concentrations can reduce the volume weight of different levels of orchard soil and improve soil porosity. The decrease of volume weight and the increase of total porosity in the $0-20 \mathrm{~cm}$ soil layer were greater than those in the $20-40 \mathrm{~cm}$ soil layer. Substituting chemical fertilizer with organic manure can improve soil $\mathrm{pH}$ and organic matter content in the different soil layers. Although alkali-hydrolysable nitrogen declined compared with conventional fertilization, it did not attain a significant difference. The concentrations of available phosphorus, potassium calcium and magnesium in soils increased compared with the control. All the treatments improved mango yield, however, there was a non-significant effect on single fruit weight. Soluble solid, vitamin $\mathrm{C}$ and solidity-acid ratio in fruits all increased, and the titratable acid content decreased compared with the control. Comprehensive comparison indicated that a 30\% substitution of organic manure is the most effective treatment to improve soil fertility and fruit quality.
\end{abstract}

Keywords: mango, organic manure, soil physical and chemical properties, yield, fruit quality

\section{Introduction}

Mango (Mangifera india L.), also called the "King of Tropical Fruits" is widely distributed in tropical and subtropical regions from $30^{\circ} \mathrm{S}$ to $30^{\circ} \mathrm{N}$. Mango was introduced to China from India during the Tang Dynasty, having a cultivation period longer than 1300years (Hu et al., 2015). In China, mango is mainly distributed in the provinces of Hainan, Guangxi, Yunnan, Sichuan, Guangdong, Guizhou and Fujian in the tropical and subtropical regions. In 2017, the total planting area in China was 3.868 million $\mathrm{Mu}$ with a yield of 2.053 million tons, making China the fourth largest producer in the world (MADOSATC, 2018).

Soil fertility provides a comprehensive reflection of the different soil properties, and it has an important effect on crop growth. Investigations using different practices and methods into improving soil fertility are important for improving crop yield and fertilizer use. The use of organic fertilizers increases soil basic fertility by applying 
organic materials to the soil in order to improve the fertilization capacity of the soil (Chen, 2015). Suitable soil fertilization is not the only key to improving soil quality, and it is also a core problem for guaranteeing the sustainable utilization of agricultural resources (Liu et al., 2006). Current research indicates that the most effective fertilization method for arable soil is by adding organic materials, namely soil organic fertilizers (Wang, 2014). Li et al. (2014) showed that the long-term application of organic manure could significantly improve the organic matter content in a soil, especially active organic matter. Results by Zeng et al. (2008) indicated that long-term application of organic manure could significantly improve the organic carbon content in the $0-30 \mathrm{~cm}$ soil layer. Moharana et al. (2012) considered that the application of organic manure was conducive to the sustainable development of agricultural production and soil quality improvement. Previously scientists indicated that the yields of tomato and potato can increase significantly after the application of organic manure (Valšíková-Frey et al., 2018; Sukri, 2018; Tamad, 2019). Findings by Zang et al. (2015) indicated that soil available nutrients and mango fruit quality were higher when chemical fertilizers were substituted with organic manure, while the suitable substitutional proportions for chemical fertilizer with organic manure still unclear.

Recently, with an improvement in mango cultivation techniques, the economic benefits of mango cultivation have significantly improved. With a change of mango cropping patterns, ahead florescence and shortened growth period, the requirements of soil nutrients have correspondingly increased. Current practices suggest mango is planted in loam and sandy loam soil, with a $\mathrm{pH}$ value around 6.5. It is also recommended that plants have good ventilation and medium soil fertility (Xu et al., 2012). However, the main mango production area in Hainan Island is located on hillsides on low mountains, having a relatively barren soil with low organic matter, available nitrogen, available phosphorus, calcium and magnesium contents were deficit (Liao et al., 2008). The application of organic manure has non-substitutable effects on improving soil structure, fertilization and nutrients (Fu et al., 2013). Findings by Han et al. (2004) showed that the application of organic manure in successive years could effectively improve soil physical properties, reduce soil volume weight, increase the effective porosity in fields and increase the water storage and retention capacity of the soil, resulting in well-developed aggregates. The practice of substituting chemical fertilizer with organic manure have mainly focused on fruit trees including tangerine, pear and apple; few studies have studies effects on mango trees (Fu et al., 2013; Moharana et al., 2012; Wang, 2014). The purpose of this study is to analyze the effects of different substitution levels of chemical fertilizer with organic manure on soil quality, fruit yield and quality in a mango orchard. The results can provide a foundation for improving soil quality, fertilization, fruit yield and quality in a mango orchard.

\section{Materials and Methods}

\section{Site location and characteristics}

The experimental field was located at Fruit Island Base in Tianya District, Sanya, Hainan province. The site was located on a hilly slope having a typical tropical insular monsoon climate with an annual average temperature of $22^{\circ} \mathrm{C}-27^{\circ} \mathrm{C}$ and annual precipitation of 1500-2000 $\mathrm{mm}$. The site has favorable light and heat conditions, and the parent soil was mainly granite weathered products. Guifei mango, which was introduced 
into Hainan Province in 1997 from Taiwan and is currently one of the main cultivars in tropical area of China, was the mango variety examined in this study which has been field planting for 12 years. Basic soil physical and chemical properties in the experimental field are shown in Table 1.

Table 1. Basic physical and chemical soil properties

\begin{tabular}{c|c|c|c|c|c|c|c}
\hline $\begin{array}{c}\text { Layer } \\
\mathbf{c m}\end{array}$ & $\mathbf{p H}$ & $\begin{array}{c}\mathbf{O M} \\
\mathbf{g} / \mathbf{k g}\end{array}$ & $\begin{array}{c}\text { Available N } \\
\mathbf{m g} / \mathbf{k g}\end{array}$ & $\begin{array}{c}\text { Available } \mathbf{P} \\
\mathbf{m g} / \mathbf{k g}\end{array}$ & $\begin{array}{c}\text { Available } \mathbf{k} \\
\mathbf{m g} / \mathbf{k g}\end{array}$ & $\begin{array}{c}\text { Available Ca } \\
\mathbf{m g} / \mathbf{k g}\end{array}$ & $\begin{array}{c}\text { Available Mg } \\
\mathbf{m g} / \mathbf{k g}\end{array}$ \\
\hline $0-20$ & 5.69 & 11.2 & 120.3 & 23.61 & 70.54 & 154.22 & 64.50 \\
$20-40$ & 5.47 & 9.9 & 103.5 & 23.17 & 58.40 & 143.16 & 55.42 \\
\hline
\end{tabular}

\section{Experiment design}

The experiment was initiated in June, 2017, after the fruit harvest season, which was April to May, and completed in June, 2018. A gradient design of different substitutional proportions for chemical fertilizer with organic manure was applied, and plants with consistent growth were selected as the test objects. Four treatments were established: (1) Conventional fertilization (CK); (2) 10\% nitrogen reduction of chemical fertilizer with organic fertilizer fermented by sheep manure (organic fertilizer fermented by sheep manure with the nutrient contents in dry basis of $2.23 \%$ nitrogen, $1.78 \% \mathrm{P}_{2} \mathrm{O}_{5}$ and $3.91 \%$ $\mathrm{K}_{2} \mathrm{O}$ ); (3) $30 \%$ nitrogen reduction of chemical fertilizer; (4) $50 \%$ nitrogen reduction of chemical fertilizer (Table 2). Nine trees were selected in each treatment, with three replicas. According to the results of He et al. (2013) and Zeng et al. (2003), 0.6kg N, $\mathrm{P}_{2} \mathrm{O}_{5} 0.3 \mathrm{~kg} \mathrm{P}_{2} \mathrm{O}_{5}$ and $0.6 \mathrm{~kg} \mathrm{~K} \mathrm{~K}_{2} \mathrm{O}$ were applied to each mango tree every year, and all fertilizers were applied at the same time.

Table 2. The experiment design of this study

\begin{tabular}{|c|c|c|c|c|c|c|}
\hline \multirow[t]{2}{*}{ Treat } & \multicolumn{2}{|c|}{$\begin{array}{c}N \\
\text { kg }\end{array}$} & \multicolumn{2}{|c|}{$\begin{array}{c}\mathbf{P}_{2} \mathbf{O}_{5} \\
\text { kg }\end{array}$} & \multicolumn{2}{|c|}{$\begin{array}{c}\mathrm{K}_{2} \mathrm{O} \\
\mathrm{kg} \\
\end{array}$} \\
\hline & Organic & Chemical & Organic & Chemical & Organic & Chemical \\
\hline CK & 0 & 0.60 & 0 & 0.30 & 0 & 0.60 \\
\hline T1 & 0.06 & 0.54 & 0.05 & 0.25 & 0.11 & 0.49 \\
\hline $\mathrm{T} 2$ & 0.18 & 0.42 & 0.14 & 0.16 & 0.32 & 0.28 \\
\hline $\mathrm{T} 3$ & 0.30 & 0.30 & 0.24 & 0.06 & 0.53 & 0.07 \\
\hline Treat & $\begin{array}{l}\text { Organic } \\
\text { manure } \\
\quad \text { kg }\end{array}$ & $\begin{array}{c}\text { Urea } \\
\text { kg }\end{array}$ & \multicolumn{2}{|c|}{$\begin{array}{c}\text { Calcium magnesium } \\
\text { phosphate } \\
\text { kg }\end{array}$} & \multicolumn{2}{|c|}{$\begin{array}{c}\text { Potassium } \\
\text { chloride } \\
\text { kg }\end{array}$} \\
\hline CK & 0 & 1.3 & \multicolumn{2}{|c|}{1.7} & \multicolumn{2}{|c|}{1.0} \\
\hline $\mathrm{T} 1$ & 2.7 & 1.2 & \multicolumn{2}{|c|}{1.4} & \multicolumn{2}{|c|}{0.8} \\
\hline $\mathrm{T} 2$ & 8.0 & 0.9 & \multirow{2}{*}{\multicolumn{2}{|c|}{0.9}} & \multirow{2}{*}{\multicolumn{2}{|c|}{0.5}} \\
\hline T3 & 13.5 & 0.7 & & 0.3 & & 0.1 \\
\hline
\end{tabular}

\section{Sample collection and analysis}

Soil and mango leaf samples were collected in May, 2018. Mango leaf samples were collected from fruit bearing shoots at the top and middle of the crown. Samples east, 
south, west and north of each tree were also collected and mixed. All samples were blanched at $105^{\circ} \mathrm{C}$ for $30 \mathrm{~min}$, dried at $75^{\circ} \mathrm{C}$ for 120 hours, ground using a plant mill and passed through a $0.149 \mathrm{~mm}$ nylon sieve. The total nitrogen was determined by $\mathrm{H}_{2} \mathrm{SO}_{4}-\mathrm{H}_{2} \mathrm{O}_{2}$-indophenol blue colorimetry, total phosphorus was determined by vanadium molybdenum yellow colorimetry, and total potassium was determined by flame photometry (Gao, 2006). The concentrations of calcium and magnesium were determined by dry ashing-dilute hydrochloric acid dissolution method (Gao, 2006).

Soil samples were collected on the drip line of mango tree, and different layers $(0-20 \mathrm{~cm}$ and $20-40 \mathrm{~cm})$ soil sampled separately in sample points. Four sample points for one mango tree, and soil samples from three trees were combined to make a composite sample. The samples were air dried, passed through a $2 \mathrm{~mm}$ sieve and stored in sealed plastic sealing bags. Before the arrangement of the experiments, mixed soil samples from the experimental field were collected and a mixed sample of the soil plough layers for each treatment was collected separately after the fruit harvest. The soil $\mathrm{pH}$ was measured using glass electrode, at 1:5 (W/V) ratio of soil: water (Lu, 2000). After oxidized by $\mathrm{K}_{2} \mathrm{Cr}_{2} \mathrm{O}_{7}$, the content of organic matter in soil was measured by the titration method (Lu, 2000). Alkali-hydrolysable nitrogen concentrations in soil was measured by diffusion method (Lu, 2000). Available phosphorus in soil was determined by hydrochloric acid-ammonium fluoride method ( $\mathrm{Lu}, 2000)$. Available potassium concentration in soil was measured by ammonium acetate extraction method, and the contents of available calcium and magnesium in soil were determined by ammonium acetate exchange-EDTA complexometric titration method (Lu, 2000).

Mango yield and fruit quality was determined by field observations. Twelve uniform fruits with $80 \%$ maturity from four directions from mango tree were collected for quality determination. Plot yield was determined according to the yields of each mango plants. The soluble solid was determined using MASTER-53T electronic refractometer, vitamin $\mathrm{C}$ was determined using the 2, 6-dichloroindophenol titration method, and titrable acid was determined using standard acid-base titration (Gao, 2006).

\section{Data analysis}

Descriptive statistics analysis and least significant difference analysis were undertaken using SAS9.0 software.

\section{Results}

\section{The effects of different concentrations of organic manure on soil physical properties}

Soil volume weight and porosity under the different treatments (Table 3) recorded a decreasing trend. Treatments $\mathrm{T} 2$ and $\mathrm{T} 3$ in the $0-20 \mathrm{~cm}$ soil layer decreased by $2.1 \%$ and $2.9 \%$ compared with the control, respectively, recording a significant difference with the control and T1. Volume weights in treatments T2 and T3 in the $20-40 \mathrm{~cm}$ soil layer decreased by $1.4 \%$ and $2.1 \%$ compared to the control, respectively, having a significant difference with the control and T1. Although a decrease in total porosity at the different soil layers was noticeable, these results were not significant. As soil depth increased, total porosity decreased; total porosity at the $20-40 \mathrm{~cm}$ soil layer was smaller than it at the $0-20 \mathrm{~cm}$ surface soil layer, indicating that the root aeration status at the $20-40 \mathrm{~cm}$ soil layer was weaker than that at the surface soil layer. 
Table 3. The effects of different concentrations of organic manure on soil physical properties $^{\text {th }}$

\begin{tabular}{c|c|c|c}
\hline Treatment & $\begin{array}{c}\text { Soil layer } \\
\mathbf{~ c m}\end{array}$ & $\begin{array}{c}\text { Volume weight } \\
\mathbf{g} / \mathbf{c m}^{\mathbf{3}}\end{array}$ & $\begin{array}{c}\text { Total porosity } \\
\mathbf{\%}\end{array}$ \\
\hline \multirow{2}{*}{$\mathrm{CK}$} & $0-20$ & $1.38 \pm 0.01 \mathrm{a}$ & $46.74 \pm 0.15 \mathrm{a}$ \\
& $20-40$ & $1.46 \pm 0.01 \mathrm{a}$ & $45.31 \pm 0.20 \mathrm{a}$ \\
\hline \multirow{2}{*}{$\mathrm{T} 1$} & $0-20$ & $1.37 \pm 0.01 \mathrm{a}$ & $45.08 \pm 0.22 \mathrm{a}$ \\
& $20-40$ & $1.45 \pm 0.01 \mathrm{a}$ & $45.12 \pm 0.22 \mathrm{a}$ \\
\hline \multirow{2}{*}{$\mathrm{T} 2$} & $0-20$ & $1.35 \pm 0.01 \mathrm{~b}$ & $44.94 \pm 0.19 \mathrm{a}$ \\
& $20-40$ & $1.44 \pm 0.01 \mathrm{~b}$ & $45.02 \pm 0.30 \mathrm{a}$ \\
\hline \multirow{2}{*}{$\mathrm{T} 3$} & $0-20$ & $1.34 \pm 0.01 \mathrm{c}$ & $44.90 \pm 0.34 \mathrm{a}$ \\
& $20-40$ & $1.43 \pm 0.00 \mathrm{c}$ & $45.01 \pm 0.19 \mathrm{a}$ \\
\hline
\end{tabular}

${ }^{\dagger}$ mean \pm standard deviation

${ }_{\mathrm{a}} \mathrm{a}, \mathrm{b}$ and $\mathrm{c}$ represent significant differences between treatments $(\mathrm{P}<0.05)$

\section{The effects of different concentrations of organic manure on soil chemical properties}

$\mathrm{pH}$ and organic matter content in the treatments recorded an increase as the proportion of organic manure increased; T2 and T3 in the $0-20 \mathrm{~cm}$ soil layer recorded significant differences compared to the control and T1. Compared with conventional methods, organic matter content in T2 and T3 increased by $27.6 \%$ and $33.6 \%$ in the $0-20 \mathrm{~cm}$ soil layer and by $28.9 \%$ and $32.3 \%$ in the $20-40 \mathrm{~cm}$ soil layer, respectively (Table 4). Compared with the control, alkali-hydrolysable nitrogen in the different soil layers decreased as the concentration of organic manure increased, results however did not record a significant difference. The contents of available phosphorus, available potassium, available calcium and magnesium increased compared with the control, and significant differences were recorded for available potassium and available magnesium in treatments $\mathrm{T} 2$ and $\mathrm{T} 3$ in the $0-20 \mathrm{~cm}$ soil layer compared with conventional fertilization and T1. No significant differences were recorded between T3 and T2. A comprehensive comparison between the concentration of organic manure indicated that $\mathrm{T} 2$ had a better effect on soil fertility than T3.

Table 4.The effects of different concentrations of organic manure on soil chemical properties $^{\text {th }}$

\begin{tabular}{|c|c|c|c|c|c|c|c|c|}
\hline Treatments & $\begin{array}{c}\text { Soil } \\
\text { layer } \\
\text { cm }\end{array}$ & pH & $\begin{array}{l}\text { OM } \\
\mathrm{g} / \mathrm{kg}\end{array}$ & $\begin{array}{c}\text { Available N } \\
\mathrm{mg} / \mathrm{kg}\end{array}$ & $\begin{array}{c}\text { Available } P \\
\mathrm{mg} / \mathrm{kg}\end{array}$ & $\begin{array}{c}\text { Available K } \\
\mathrm{mg} / \mathrm{kg}\end{array}$ & $\begin{array}{c}\text { Available Ca } \\
\mathrm{mg} / \mathrm{kg}\end{array}$ & $\begin{array}{c}\text { Available } \\
\text { Mg } \\
\text { mg/kg }\end{array}$ \\
\hline \multirow{2}{*}{ CK } & $0-20$ & $5.68 \pm 0.04 \mathrm{a}$ & $9.30 \pm$ & $70.66 \pm 2.15 \mathrm{a}$ & $20.61 \pm 0.44 \mathrm{a}$ & $217.45 \pm 0.47 \mathrm{a}$ & $433.24 \pm 1.13 \mathrm{a}$ & $48.43 \pm 0.49 \mathrm{a}$ \\
\hline & $20-40$ & $5.51 \pm 0.02 \mathrm{a}$ & $8.10 \pm 1.34 \mathrm{a}$ & $66.43 \pm 1.72 \mathrm{a}$ & $21.82 \pm 0.76 \mathrm{a}$ & $235.41 \pm 1.02 \mathrm{a}$ & $441.63 \pm 1.27 \mathrm{a}$ & $44.05 \pm 0.41 \mathrm{a}$ \\
\hline \multirow[b]{2}{*}{1} & $0-20$ & $5.71 \pm 0.02 \mathrm{a}$ & $9.50 \pm 2.43 \mathrm{a}$ & $65.43 \pm 1.95 \mathrm{a}$ & $21.47 \pm 0.42 \mathrm{a}$ & $225.20 \pm 1.48 \mathrm{a}$ & $439.35 \pm 3.58 \mathrm{a}$ & $46.25 \pm 0.33 \mathrm{a}$ \\
\hline & $20-40$ & $5.66 \pm 0.03 \mathrm{a}$ & $8.86 \pm 1.79 \mathrm{a}$ & $62.45 \pm 1.43 \mathrm{a}$ & $17.46 \pm 0.45 \mathrm{a}$ & $223.19 \pm 1.26 \mathrm{a}$ & $410.47 \pm 2.54 \mathrm{a}$ & $43.11 \pm 0.47 \mathrm{a}$ \\
\hline \multirow{2}{*}{$\mathrm{T} 2$} & $0-20$ & $5.74 \pm 0.10 \mathrm{~b}$ & $11.87 \pm 2.54 \mathrm{~b}$ & $62.1 \pm 0.68 \mathrm{a}$ & $28.50 \pm 0.35 b$ & $241.2 \pm 2.24 \mathrm{~b}$ & $443.8 \pm 4.61 \mathrm{a}$ & $57.54 \pm 0.57 \mathrm{~b}$ \\
\hline & $20-40$ & $5.69 \pm 0.11 \mathrm{a}$ & $10.44 \pm 1.93 b$ & $59.43 \pm 0.77 \mathrm{a}$ & $18.73 \pm 0.41 \mathrm{a}$ & $198.48 \pm 0.52 \mathrm{a}$ & $401.76 \pm 2.49 \mathrm{a}$ & $54.81 \pm 1.12 \mathrm{a}$ \\
\hline \multirow{2}{*}{ T3 } & $0-20$ & $6.12 \pm 0.02 \mathrm{c}$ & $12.43 \pm 2.91 \mathrm{c}$ & $59.47 \pm 2.44 \mathrm{a}$ & $28.76 \pm 0.64 b$ & $293.31 \pm 2.15 b$ & $446.29 \pm 3.44 \mathrm{a}$ & $59.48 \pm 1.07 \mathrm{~b}$ \\
\hline & $20-40$ & $5.84 \pm 0.06 b$ & $10.72 \pm 1.18 \mathrm{~b}$ & $59.26 \pm 2.01 \mathrm{a}$ & $19.64 \pm 0.55 \mathrm{a}$ & $195.72 \pm 1.99 \mathrm{a}$ & $386.28 \pm 3.02 \mathrm{a}$ & $55.79 \pm 0.88 \mathrm{a}$ \\
\hline
\end{tabular}

${ }^{\dagger}$ mean \pm standard deviation

$\star \mathrm{a}, \mathrm{b}$ and $\mathrm{c}$ represent significant differences between treatments $(\mathrm{P}<0.05)$ 


\section{The effects of different concentrations of organic manure on leaf mineral nutrients}

Mineral element content results in mango leaves under different treatments (Table 5) recorded a reduction of total nitrogen content and an increase of total phosphorus, total potassium, calcium and magnesium compared to the control. However, results did not record a significant difference, indicating that there were non-significant effects of the substitution of chemical fertilizer with organic manure on the absorption of nutrients in mango leaves.

Table 5. The concentrations of mineral nutrients in mango leaves ${ }^{H *}$

\begin{tabular}{c|c|c|c|c|c}
\hline Treatments & $\begin{array}{c}\text { Total N } \\
\mathbf{\%}\end{array}$ & $\begin{array}{c}\text { Total P } \\
\mathbf{\%}\end{array}$ & $\begin{array}{c}\text { Total K } \\
\mathbf{\%}\end{array}$ & $\begin{array}{c}\text { Ca } \\
\mathbf{\%}\end{array}$ & $\begin{array}{c}\text { Mg } \\
\mathbf{\%}\end{array}$ \\
\hline CK & $1.78 \pm 0.04 \mathrm{a}$ & $0.12 \pm 0.10 \mathrm{a}$ & $0.46 \pm 0.02 \mathrm{a}$ & $1.74 \pm 0.03 \mathrm{a}$ & $0.21 \pm 0.04 \mathrm{a}$ \\
$\mathrm{T} 1$ & $1.79 \pm 0.02 \mathrm{a}$ & $0.12 \pm 0.01 \mathrm{a}$ & $0.47 \pm 0.02 \mathrm{a}$ & $1.75 \pm 0.13 \mathrm{a}$ & $0.21 \pm 0.11 \mathrm{a}$ \\
$\mathrm{T} 2$ & $1.78 \pm 0.07 \mathrm{a}$ & $0.12 \pm 0.11 \mathrm{a}$ & $0.47 \pm 0.02 \mathrm{a}$ & $1.78 \pm 0.09 \mathrm{a}$ & $0.21 \pm 0.09 \mathrm{a}$ \\
T3 & $1.77 \pm 0.01 \mathrm{a}$ & $0.12 \pm 0.02 \mathrm{a}$ & $0.47 \pm 0.01 \mathrm{a}$ & $1.76 \pm 0.07 \mathrm{a}$ & $0.22 \pm 0.05 \mathrm{a}$ \\
\hline
\end{tabular}

†mean \pm standard deviation

$\star \mathrm{a}, \mathrm{b}$ and $\mathrm{c}$ represent significant differences between treatments $(\mathrm{P}<0.05)$

\section{The effects of different concentrations of organic manure on fruit yield and quality}

Compared with conventional fertilization, there were non-significant effects for treatments with different concentrations of organic manure on crop yield (Table 6) or single fruit weight. However, soluble solid, Vc and solidity-acid ratio in fruits all increased, with the proportions in $\mathrm{T} 2$ increasing by $23.7 \%, 6.4 \%$ and $16.34 \%$ compared to the control, respectively. Although the soluble solid content in treatment $\mathrm{T} 1 \mathrm{did}$ not reach a significant difference compared to the control, it did record a significant difference compared with $\mathrm{T} 2$ and $\mathrm{T} 3$. The titratable acid contents in fruits under different treatments decreased compared to the control, recording a significant difference. Non-significant differences between vitamin $\mathrm{C}$ and titratable acid in $\mathrm{T} 2$ and T3 were also recorded.

Table 6.The results of mango fruit yield and quality

\begin{tabular}{c|c|c|c|c|c|c}
\hline Treatment & $\begin{array}{c}\text { Yield } \\
\text { kg/plant }\end{array}$ & $\begin{array}{c}\text { Single fruit weight } \\
\mathbf{~ k g}\end{array}$ & $\begin{array}{c}\text { Soluble solid } \\
\mathbf{\%}\end{array}$ & $\begin{array}{c}\text { vitamin C } \\
\mathbf{m g} / \mathbf{1 0 0 g}\end{array}$ & $\begin{array}{c}\text { Titratable acids } \\
\mathbf{\%}\end{array}$ & $\begin{array}{c}\text { Solidity-acid ratio } \\
\mathbf{\%}\end{array}$ \\
\hline $\mathrm{CK}$ & $45.7 \pm 0.4 \mathrm{a}$ & $0.22 \pm 0.21 \mathrm{a}$ & $10.04 \pm 0.24 \mathrm{a}$ & $2.03 \pm 0.17 \mathrm{a}$ & $0.253 \pm 0.022 \mathrm{c}$ & $35.73 \pm 0.94 \mathrm{a}$ \\
$\mathrm{T} 1$ & $45.2 \pm 0.5 \mathrm{a}$ & $0.25 \pm 0.09 \mathrm{a}$ & $11.18 \pm 0.22 \mathrm{a}$ & $1.75 \pm 0.26 \mathrm{a}$ & $0.247 \pm 0.014 \mathrm{~b}$ & $37.17 \pm 0.85 \mathrm{a}$ \\
$\mathrm{T} 2$ & $45.9 \pm 0.7 \mathrm{a}$ & $0.24 \pm 0.16 \mathrm{a}$ & $12.42 \pm 0.08 \mathrm{~b}$ & $2.16 \pm 0.09 \mathrm{a}$ & $0.241 \pm 0.016 \mathrm{a}$ & $41.57 \pm 1.02 \mathrm{~b}$ \\
$\mathrm{~T} 3$ & $46.3 \pm 0.6 \mathrm{a}$ & $0.23 \pm 0.20 \mathrm{a}$ & $12.81 \pm 0.21 \mathrm{c}$ & $2.17 \pm 0.12 \mathrm{a}$ & $0.240 \pm 0.031 \mathrm{a}$ & $42.37 \pm 1.34 \mathrm{c}$ \\
\hline
\end{tabular}

†mean \pm standard deviation

$\star_{\mathrm{a}}, \mathrm{b}$ and $\mathrm{c}$ represent significant differences between treatments $(\mathrm{P}<0.05)$ 


\section{Discussion}

\section{The effects on soil physical properties}

In mango orchard, the application of organic manure could effectively improve the soil environment, reduce soil volume weight, and increase total porosity. And this is consistent with the results of Ge (2018). Ma et al. (2010) also indicated that the application of organic manure, as well as the combined application of chemical fertilizer and organic manure, could effectively improve soil physical properties, decrease soil volume weight, and increase total porosity and effective porosity.

\section{Effects on soil fertility improvement}

Soil $\mathrm{pH}$ and contents of organic matters in mango orchard increased under treatments $\mathrm{T} 2$ and $\mathrm{T} 3$ in the $0-20 \mathrm{~cm}$ and $20-40 \mathrm{~cm}$ soil layers. Organic matter attained a significant level, similar to the results of Zang et al. (2015). By substituting chemical fertilizer with organic manure, soil $\mathrm{pH}$ increased, however non-significant differences were recorded between each treatment. Soil mineral nutrition was the direct nutrient resource for fruit tree growth and fruit development (Chen et al., 2018). In our study, alkali-hydrolysable nitrogen decreased, and available phosphorus, available potassium, available calcium and magnesium increased to a certain extent compared to the control. Our findings indicated that $\mathrm{T} 2$ recorded the best enhancement effects on soil nutrients. In each treatment, the contents of available calcium and magnesium increased to a certain extent, a finding that may be related to an increase in cation content in the soil due to a certain amount of ash elements, including calcium and magnesium, contained in the organic manure (Zhu et al., 2012). Under the hot and humid soil conditions in southern China, soil acidification in orchards is the result of long-term and large-scale application of chemical fertilizers, as well as lack of organic manure in the orchard soil. The addition of organic manure can improve the soil quality by not only increasing soil $\mathrm{pH}$, but also by improving soil fertility, thus improving fruit quality and guaranteeing the sustainable production and development of fruit trees (Zhao, 2013). Therefore, the combined application of chemical fertilizer with organic manure is not only conducive to the improvement and fertility of the soil, it also increases the capacity for supplying and preserving fertilizers in the orchard soil (Zang et al., 2016).

\section{Effects on fruit yield and quality}

Due to the effects of field condition and the growth cycle of mango trees, all of the treatments improved fruit yield to a certain extent, however they did not attain significant differences. After the application of organic manure, there were certain effects on the contents of soluble solid, vitamin $\mathrm{C}$ and titrable acid in the fruits. Soluble solid, vitamin $\mathrm{C}$ and solidity-acid ratio all recorded an increasing trend; when the substitution proportion of chemical fertilizer with organic manure was $30 \%$, soluble solid, vitamin $\mathrm{C}$ and the solidity-acid ratio increased by $23.7 \%, 6.4 \%$ and $16.34 \%$ compared to the control, respectively. Titrable acid slightly decreased, this being similar to previous findings (Lai et al., 2011; Wan et al., 2012; Zhang et al., 2018). 


\section{Conclusions}

In mango orchard, substituting chemical fertilizer with organic manure can decrease soil volume weight, improve total porosity, and significantly increased the soil $\mathrm{pH}$ and organic matter content. Available nutrients concentrations in soil increased compared to the control. Substituting chemical fertilizer with organic manure improved mango yields and increased soluble solids, vitamin $\mathrm{C}$ content and the solidity-acid ratio. Comprehensive comparison indicated that a $30 \%$ substitution of organic manure is an economic and effective treatment to improve soil fertility and fruit quality.

Acknowledgments. This research was supported by The National Key Research and Development Program of China (2017YFD0202100), Key Research and Development Program of Hainan Province Hainan Province (ZDYF2018065), Major Science and Technology Program of Hainan Province (ZDKJ2017003) and the Central Public-interest Scientific Institution Basal Research Fund for Chinese Academy of Tropical Agricultural Sciences (1630032017042).

\section{REFERENCES}

[1] Chen, C. (2015): Effects of different manures and their mixed application on soil microbiological properties and corn yield. - Jilin Agriculture University.

[2] Chen, R. Z., Li, J., Fan, J. H., Lin, D. (2018): Effects of different fertilizer ratio on soil nutrient, microbial quantity. - Chinese Journal of Tropical Crops 39: 1055-1060.

[3] Fu, C. Y., Zhang, X. F., Wang, Y. J., Wang, S. X., Cui, S. M. (2013): Effects of organic fertilizer and sulfur application on the growth of Nanfeng tangerine and chemical properties of calcareous soil under greenhouse. - Soil and Fertilizer Sciences in China 2: 17-21.

[4] Gao, J. F. (2006): Guidance of plant physiology experiments. - Higher Education Press, Beijing 74-77.

[5] Ge, X. W. (2018): Effects of different organic fertilizers on soil quality and wine grape quality in orchard. - Ningxia University.

[6] Han, B. J., Chen, Y., Qiao, Y. F., Han, X. Z., Meng, K. (2004): Effect of long-term application organic fertilizer on soil physiochemical properties. System. - Sciences and Comprehensive Studies in Agriculture 20: 294-296.

[7] He, L. J. (2013): The impact of different fertilization levels and methods on yield of mango in northern mountain area of Tianyang County. - Journal of Guangxi Agriculture 28:21-23.

[8] Hu, Y., Zhang, D. S., Liu, K. D. (2015): Developing history and influence factors of the mango industry in China. - Chinese Journal of Agricultural Resources and Regional Planning 36: 53-59.

[9] Lai, Y., Tong, Y. A., Chen, L. L., Gao, Y. M., Yang, J. F. (2011): Effect of fertilization on Kiwifruit yield and quality. - Journal of Northwest A \& F University(Natural Science Edition) 39: 171-176.

[10] Li, J., Yang, X. Y., Sun, B. H., Zhang, S. L. (2014): Effects of soil management practices on stability and distribution of aggregates in Lou soil. - Journal of Plant Nutrition and Fertilizer 20: 346-354.

[11] Liao, X. J., Tang, S. M., Wu, D., Feng, Y. S., Xia, C. J. (2008): Effect of the soil environment of mango plantation on mango quality in Hainan province. - Ecology and Environment 17: 727-733.

[12] Liu, Z. F., Fu, B. J., Liu, G. H., Zhu, Y.G. (2006): Soil quality: concept, indicators and its assessment. - Acta EcologicaSinica 26: 901-913. 
[13] Lu, R. K. (2000): Soil Agricultural Chemistry Analysis. - China Agriculture Science\& Technology Press.

[14] Ma, J. Y., Cao, C. Y., Zheng, C. L., Li, K. J., Ren, T. S. (2010): Effect of Long-term application of chemical fertilizers and organic manure on soil organic carbon and bulk density. - Soil and Fertilizer Sciences in China 6: 38-42.

[15] Ministry of Agriculture Development Office of South Asia Tropical Crops (MADOSATC). (2018): Crop production in tropical and subtropical regions of China. Ministry of Agriculture Development Office of South Asia Tropical Crops, Beijing China.

[16] Moharana, P. C., Sharma, B. M., Biswas, D. R., Dwivedi, B. S., Singh, R. V. (2012): Long-term effect of nutrient management on soil fertility and soil organic carbon pools under a 6 years old pearl millet-wheat cropping system in an inceptisol of subtropical India. - Field Crops Research 136: 32-41.

[17] Sukri, M. Z., Sari, V. K., Firgiyanto, R. (2018): Improving soil fertilizer through application of organic fertilizer humid acid and mikoriza in supporting growth and production of chilli plants in sand land. - Earth and Environ Sciences 207: 1-6.

[18] Tamad, Soesanto, L., Rostaman, R., Agustin, P. E., Khoiriyah, N. (2019): Enhancing potato (Solanum tuberosum L.) yield by using biological organic fertilizers and soil conservation practices on the slope andisol. - Earth and Environ Sciences 250:012098.

[19] Valšíková-Frey, M., Sopková, D., Rehuš, M., Komár, P. (2018): Impact of Organic Fertilizers on Morphological and Phenological Properties and Yield of Tomatoes. - Acta Hortic et Regiotecturae 21: 48-53.

[20] Wan, S. X., Li, F., Jiang, G. Y., Wang, W. J., Zhu, H. B. (2012): Effects of different organic fertilizer rates on soil microbe and quality and yield of cabbage. - Soil and Fertilizer Sciences in China 6: 74-76.

[21] Wang, F. (2014): Effects of organic amendments on soil fertility and plant growth. Northwest A \& F University.

[22] Xu, L. B., Gao, A. P., Pu, J. J., Wu, Y. L., Zhu, M., Huang, J. F. (2012): Technical guidelines for safety production of banana and mango. - China Agriculture Publishing Press, Beijing, China 11-22.

[23] Zang, X. P., Lin, X. E., Zhou, Z. X., Tan, L., Ge, Y., Dai, M. J., Ma, W. H. (2015): Effects of different fertilization treatments on quality of mango fruit and soil fertility. Subtropical Plant Science 44: 146-149.

[24] Zang, X. P., Zhou, Z. X., Lin, Y. E., Dai, M. J., Ge, Y., Liu, Y. X., Ma, W. H. (2016): Effects of different organic manure application rate on mango fruit quality and soil fertility. - Soil and Fertilizer Sciences in China 1: 98-101.

[25] Zeng, F. Z., Cao, H. L., Huang, J. Q., Wu, G. Y., Zhang, D. Q. (2003): Soil Characteristics and Fertility Regulation of Mango Orchard in Laterite Red Soil. Agriculturel Sciences Guangdong Province 25-27.

[26] Zeng, J., Guo, T. W., Bao, X. G., Wang, Z., Sun, J. H. (2008): Effections of soil organic carbon and soil inorganic carbon under long- term fertilization. - Soil and Fertilizer Sciences in China2:11-14.

[27] Zhang, M., Yao, Y. L., Tian, Y. H., Ceng, K., Zhao, M., Zhao, M., Yin, B. (2018): Increasing yield and $\mathrm{N}$ use efficiency with organic fertilizer in Chinese intensive rice cropping systems. - Field Crops Research 227: 102-109.

[28] Zhao, L., Liu, C. T. (2013): Effects of different organic materials on soil fertility and aggregates stability. - Journal of Northwest A \& F University(Natural Science Edition) 41: 130-136, 144.

[29] Zhu, C. B., Wu, S. H., Zhang, X. Y., Zhou, D. P., Fan, J. Q., Jiang, Z. F. (2012): Effects of application of manure and microbial fertilizer on soil fertility and leaf nutrient. Chinese Agricultural Science Bulletin 28: 201-205. 